\title{
KRITIK SOSIAL DALAM KUMPULAN CERPEN “KONVENSP" KARYA A. MUSTOFA BISRI \\ SOCIAL CRITICISM IN "KONVENSI" SHORT STORY WRITTEN BY A. MUSTOFA BISRI
}

Naskah masuk: 18 Juli 2020, direview: 2 Februari 2021, disetujui: 6 April 2021

\author{
Nizar Halimatus S. ${ }^{1}$, Ferdi Arifin ${ }^{2}$ \\ FAB IAIN Surakarta \\ Pos-el: nihasa.98@gmail.com
}

\begin{abstract}
ABSTRAK
Penelitian ini berisi tentang kritik sosial dalam kumpulan cerita pendek berjudul "Konvensi" karya A. Mustofa Bisri. Penelitian ini bersifat deskriptif kualitatif dengan teori-teori sosial dari Soerjono Soekanto dan Budi Sulistyowati. Pengumpulan data dilakukan dengan cara pengambilan dari dokumen dan catatan -catatan. Klasifikasi data dilakukan dengan mengkategorikan data-data yang ditemukan berdasarkan jenis-jenis permasalahan sosial masyarakat yang ditemukan. Analisis data dilakukan dengan tahap cara analisis isi dokumen. Hasil dari penelitian ini menunjukkan bahwa dalam kumpulan cerpen "Konvensi" karya A. Mustofa Bisri telah ditemukan sembilan jenis permasalahan sosial dengan dua belas subbab permasalahan. Masing-masing subbab merupakan cerminan dari kondisi permasalahan sosial yang tengah dialami masyarakat pada saat karya itu ditulis.
\end{abstract}

Kata kunci: kritik sosial, cerita pendek.

\section{ABSTRACT}

This research studies contains social criticism in a collection of short stories titled "Konvensi" by A. Mustofa Bisri. This research is descriptive qualitative with social theories from Soerjono Soekanto and Budi Sulistyowati. Data collection is carried out by means of retrieval from documents and records. Data classification is done by categorizing the data found based on the types of social problems that are found. Data analysis was carried out with the stage of how to document the contents of the document. The results of this study indicate that in the collection of short stories "Konvensi" by A. Mustofa Bisri have found 9 types of social problems with 12 sections of problems. Each section is a reflection of the conditions of social problems that were being experienced by the community at the time the work was written.

Keywords: social criticism, short stories.

\section{PENDAHULUAN}

Sastra secara tidak langsung sering berperan sebagai dokumen dari segala tindakan masyarakat, baik tindakan terpuji maupun tercela. Adanya materialisme mekanik yang muncul pada abad ke-17 sampai ke-18 memaparkan bahwasanya hubungan material masyarakat dengan budaya mempunyai peran aktif dalam kesadaran masyarakat. Hal tersebut mengakibatkan adanya perubahan sosial justru menekankan terhadap karakter nasional dan iklim dalam perkembangan sastra itu sendiri (Endraswara, 2013: 33-34). Oleh karena itulah, hubungan antara struktur sosial dan sastra kadang tidak dapat dipahami dengan baik.

Ditegaskan oleh pendapat Pradopo (2011: 33) bahwa kesusastraan tidak lain bersumber dari bentuk kehidupan jiwa manusia yang menjelma ke dalam bentuk ragam 
bahasa tulis dengan mencerminkan fenomena kehidupan masyarakat ketika karya sastra tersebut diciptakan. Pendapat Pradopo tersebut dikuatkan oleh Escarpit (2008: 6) bahwa pada sekitar tahun 1800, mulai ada pemahaman bahwasanya terdapat dimensi sosial kesusastraan. Adanya karya Madame de Stael yang ditulis waktu itu membahas tentang "De la literature consideree dans ses rapports avec les institutions sociales" yang artinya 'kesusastraan ditinjau dari hubungannya dengan lembaga-lembaga sosial', ternyata tidak lain adalah usaha awal di Prancis untuk menafsirkan masalah masyarakat dan sastra dalam suatu himpunan yang diolah dalam sebuah studi sistematis.

Kedekatan antara karya sastra dan masyarakat akan terjadi selamanya. Pendapat tersebut didukung oleh Eagleton bahwa karya sastra lahir sesuai zamannya baik disadari ataupun tidak. Oleh karena itu, karya sastra menggambarkan kondisi sosial masyarakat ketika karya itu ditulis. Maka dari itu, tentu saja karya sastra diciptakan dengan banyak persiapan hingga ia dapat melewati dimensi ruang maupun waktu. Meskipun karya sastra diciptakan secara individual, tetapi output dari karya sastra itu sendiri tidak lepas dari budaya dan konvensi yang didapatkan melalui representasi fakta fenomena sosial masyarakat, meskipun tidak lepas dari imaji pengarang (Ratna, 2003: 34).

Etika dan estetika telah menemukan posisi yang proposional dalam dunia seni, khususnya karya sastra. Melalui bahasa, metaforis konotatif, dan stilistika, menjadikan amanat atau pesan-pesan pengarang yang disampaikan kepada pembaca terkesan bukan aturan atau norma, melainkan sebuah keindahan kata-kata. Oleh karena itu, melalui kolaborasi antara bahasa dan sastra maka lebih berhasil untuk mengubah pola tingkah laku manusia dari pada undang-undang hukum secara formal. Hal tersebut dikarenakan secara global, masyarakat yang dapat menghargai kesenian, memiliki hubungan sosial yang harmonis (dalam Ratna 2007: 297).

Karya sastra menurut Priyatni memiliki berbagai macam bentuk. Pada penelitian ini, cerpen dipilih untuk dikaji karena permasalahan dan peristiwa yang disajikan memang singkat, tetapi memiliki pesan yang dalam. Maka dari itu, pelaku yang diceritakan pun juga relatif sedikit (Abidin, 2016: 14). Pengarang menjadikan karya sastra cerpen sebagai objek penelitian karena adanya kehidupan sosial masyarakat yang dapat digambarkan dan dapat dipahami secara sederhana. Mengingat karya sastra memiliki hubungan erat dengan kondisi sosial masyarakat pada masa di mana karya sastra tersebut diluncurkan.

Melalui pendekatan sosiologi sastra, maka dianggap relevan untuk membandingkan dan mengkaji fenomena yang ada di dalam karya sastra dengan kenyataan yang ada. Mengkaji relevansi antara permasalahan-permasalahan sosial seperti masyarakat yang sering bersikap seenaknya sendiri terhadap orang lain, manipulasi politik, berdusta, sombong, dan angkuh dalam karya sastra dengan potret kehidupan nyata. Berdasarkan kedua pendekatan tersebut akan didapatkan hubungan antara karya sastra dan kehidupan masyarakat serta kehidupan masyarakat dan karya sastra, yang nantinya akan melahirkan kritik sosial kehidupan masyarakat.

Sejalan dengan pendapat Soekanto dan Sulistyowati (2015: 319-327) bahwa berdasarkan jenisnya, permasalahan sosial dibedakan menjadi sembilan macam, yaitu (1) pelanggaran terhadap norma masyarakat, (2) kemiskinan, (3) birokrasi, (4) kependudukan, (5) kejahatan, (6) disorganisasi keluarga, (7) lingkungan hidup, (8) generasi muda dalam masyarakat moderen, dan (9) peperangan.

\section{METODE PENELITIAN}

Penelitian ini berbentuk deskriptif kualitatif. Jadi tidak terlalu terfokus pada tempat penelitian. Sumber data dalam penelitian ini bersumber dari dokumen, berupa buku 
kumpulan cerpen "Konvensi" karya A. Mustofa Bisri yang diterbitkan oleh DIVA Press pertama kali pada bulan November 2018.

Teknik pengumpulan data dalam penelitian ini menggunakan studi literatur dan analisis isi dokumen kumpulan cerpen "Konvensi". Klasifikasi data dalam penelitian ini adalah dengan mengategorikan data-data yang ditemukan berdasarkan jenis-jenis permasalahan sosial yang sudah dijelaskan dalam landasan teori. Teknik analisis penelitian ini adalah analisis isi dokumen dengan tujuan memperoleh data tentang macam-macam kritik sosial yang terdapat dalam kumpulan cerpen "Konvensi" karya A. Mustofa Bisri dengan melihat kondisi sosial masyarakat saat cerpen tersebut ditulis. Cara kerja analisis isi dokumen adalah dengan membaca secara saksama keseluruhan kumpulan cerpen "Konvensi", kemudian memilah dan menghimpun data sesuai teori yang digunakan. Data tersebut dapat disajikan dalam bentuk kutipan-kutipan yang akhirnya dapat dianalisis dan dibandingkan antara permasalahan-permasalahan sosial yang ada di kehidupan nyata dengan yang digambarkan dalam karya sastra.

\section{HASIL DAN PEMBAHASAN}

Suatu masalah sering kali dapat diklasifikasikan menjadi lebih dari satu jenis. Perbedaan dalam mengklasifikasi tersebut bersumber dari adanya kepincangan warisan baik secara biologis, fisik, dan sosial yang akhirnya berdampak terhadap kebijaksanaan sosial yang diterapkan oleh masyarakat (Soekanto dan Sulistyowati, 2015: 315). Oleh karena itu, berdasarkan kumpulan cerpen "Konvensi" karya A. Mustofa Bisri maka didapatkan hasil analisis mengenai kritik sosial sebagai berikut.

\subsection{Pelanggaran Terhadap Norma-Norma Masyarakat \\ a. Pelacuran}

Kumpulan cerpen Konvensi karya A. Mustofa Bisri tidak banyak mengandung kritik mengenai pelanggaran norma pelacuran. Hanya ditemukan tiga cerpen yang menyinggung mengenai pelacuran, yaitu cerpen berjudul "Syabakhronni dan KawanKawan", "Nasihat Kyai Luqni", dan "Di Jakarta". Hal tersebut dapat dilihat dari kutipan berikut.

"Apanya yang menarik dari wanita itu? Dia bukan gadis lagi dan wajabnya kasar begitu!” (Bisri, 2018: 7).

"Sebaliknya, di antara kalian pasti ada yang pernah membaca berita tentang seorang tokoh yang meninggal di sebuah kamar hotel dan maaf-berada di atas seorang wanita nakal.” (Bisri, 2018: 54).

"Itu belum seberapa; acap kali ada saja perempuan iseng yang menggoda dan meminta lebih dari sekadar pijat." (Bisri, 2018: 114).

Kutipan tersebut menjelaskan bahwa masih banyak kasus pelacuran yang terjadi di tengah masyarakat. Pelacuran merupakan sebuah kegiatan yang harus segera dihentikan karena dapat merusak norma-norma yang ada di masyarakat. Selain itu, adanya pelacuran atau melakukan seks dengan tiada komitmen sangatlah memiliki efek samping yang buruk, terlebih untuk pihak perempuan.

Diperkuat dengan pendapat Lickona (2015: 512-513) bahwa melakukan hubungan seks memang menyenangkan. Akan tetapi, hampir seluruh remaja perempuan berakhir dengan penyesalan yang mendalam setelah melaksanakan seks. Rasa penyesalan itupun datang tidak hanya sebentar, akan tetapi hingga bertahun-tahun dan bahkan sampai tua. Hal tersebut sebagai akibat karena mereka telah memberikan hal paling berharga kepada orang yang salah.

Kutipan-kutipan di atas ditulis oleh A. Mustofa Bisri pada rentan tahun 2002 sampai 2006 di daerah Rembang Jawa Tengah. Pada rentan tahun-tahun tersebut 
banyak sekali ditemukan kasus-kasus mengenai jual beli manusia dan PSK. Seperti yang dilansir oleh berita kompas pada tanggal 18 April 2008 mengenai rekap kasus perdagangan manusia. Tahun 2004 di wilayah kota besar Semarang terdapat empat orang mendekam di penjara, diduga terlibat penjualan gadis di bawah umur. Tahun 2006 di Kabupaten Banyumas ditemukan tujuh gadis menjadi korban jaringan perdagangan wanita. Oleh karena itu, hal yang ditulis oleh A. Mustofa Bisri memang menggambarkan kondisi masyarakat sekitarnya. Dibuktikan dengan tempat ia menulis cerita pendek dengan kasus-kasus perdagangan wanita yang ditemukan di Jawa Tengah.

Selain itu, kutipan "Apanya yang menarik dari wanita itu? Dia bukan gadis lagi dan wajahnya kasar begitu!" (Bisri, 2018: 7) memiliki susunan kalimat yang lebih menjurus kepada perempuan pekerja seks daripada kutipan yang lain. Hal tersebut dikarenakan pada tahun itu perempuan kurang diperhatikan. Dikuatkan oleh Wijaksana (2001: 13) dalam jurnalnya yang memaparkan bahwa kalangan LSM banyak yang mencemaskan kepemimpinan Megawati karena track record-nya yang tidak pernah menunjukkan keberpihakan terhadap gerakan perempuan. Isu-isu mengenai perempuan Indonesia kurang mendapatkan perhatiannya, seperti isu TKW yang disiksa, diperkosa, dipenjara, dan bahkan dihukum mati. Padahal untuk beberapa kasus yang terjadi, otoritas Megawati amat dibutuhkan untuk melaksanakan advokasi, minimal melalui peryataan publik. Terlebih semenjak ia menjabat sebagai wakil presiden, setidaknya sudah mulai bersinggungan seperti kasus Imas yang menyembunyikan anak hasil perkosaan majikannya, kasus ART Kartini yang diancam pancung, atau kasus Zaenab yang didakwa hukum mati karena membunuh majikan yang kejam.

Berdasarkan kutipan dan analisis di atas maka kritik yang didapat adalah untuk para masyarakat, khususnya warga perempuan agar tidak melibatkandiri dalam kegiatan pelacuran atau seks dengan tiada komitmen. Tidak ada manfaat yang dapat diambil dari kegiatan pelacuran. Akan tetapi resiko yang diterima malah banyak dan berat. Mulai dari resiko kesehatan psikis sampai penilaian buruk dari masyarakat sehingga tidak dapat menjalankan peran sosial dengan baik dan benar.

\section{b. Delinkuensi Anak}

Delinkuensi tidak akan pernah diterima dengan baik oleh masyarakat karena dirasa menyeleweng dari adat istiadat atau norma yang telah dijalani masyarakat dalam lingkungan tersebut selama berabad-abad. Soekanto dan Sulistyowati (2015: 329) memaparkan bahwa delinkuensi anak di Indonesia ini rata-rata dilakukan oleh kelompok sosial masyarakat tertentu.

"Kalangan tua di kampung, rata-rata tidak begitu suka kepada Mas Martopo. Soalnya, menurut mereka, Mas Martopo sering melecebkan perilaku yang sudah merupakan kebiasaan orang kampung, seperti ziarah kubur, selamatan, silaturrahmi kepada kiai minta berkah atau doa-doa, dsb.” (Bisri, 2018: 89-90).

"Disetiap kesempatan, Mas Martopo memang tidak pernah lupa mengkritik kebiasaankebiasaan yang ia anggap tidak sesuai dengan ajaran agama itu. Terutama Mas Martopo paling semangat bila mengecam apa yang ia sebut sebagai klenik.” (Bisri, 2018: 90).

Kurangnya sikap toleransi yang dimiliki oleh tokoh Mas Martopo menjadikan pemicu masalah sosial di lingkungan tersebut. Kurangnya sikap toleransi yang dimiliki oleh tokoh Mas Martopo menjadikannya bertindak melecehkan, mengkritik, bahkan mengecam kebudayaan-kebudayaan yang dimiliki oleh masyarakat lingkungannya.

Sikap toleransi sebenarnya tidak dapat dipisahkan dengan sikap hormat. Meski nilai sikap toleransi berpeluang untuk berbaur dengan relativisme netral untuk menanggulangi berbagai macam prasangka yang berhubungan dengan etika. Namun 
nyatanya nilai sikap toleransi akhirnya menjadi salah satu tolak ukur dalam menjalani kehidupan yang beradap (Lickona, 2015:74-75). Oleh karena itulah nilai sikap toleransi dapat dijadikan sebagai salah satu alat untuk terciptanya kehidupan yang lebih humanis sehingga berkurangnya masalah sosial perpecahan akibat adanya perbedaan.

Kutipan tersebut ditulis oleh A. Mustofa Bisri dalam cerpennya berjudul "Mbah Mar" yang ditulis pada tahun 2018. Kenyataannya, pada tahun 2018 Kementerian Pendidikan dan Budaya (Kemendikbud) menyelenggarakan Kongres Kebudayaan Indonesia (KKI). Pada acara Pra Kongres Kebudayaan Indonesia III Muhadjir Effendy menjelaskan bahwa untuk detik ini bangsa Indonesia tengah mengalami berbagai konflik budaya intoleransi. Oleh karena itu, masyarakat harus memiliki sikap tenggang rasa dan toleransi. Segala macam tindakan intoleransi harus diperangi bersama-sama (Maulipaksi, 2018).

Indonesia memang memiliki kekayaan budaya. Budaya-budaya yang beraneka ragam tersebut harus dijaga karena bentuk jati diri bangsa. Adanya KKI bertujuan untuk mengenalkan segala macam budaya terhadap masyarakat serta mendorong keterlibatan generasi muda dalam melestarikan budaya. Akan tetapi, budaya yang dimiliki oleh masyarakat tidak hanya sekadar tari, musik, rumah adat, dan lagu daerah. Lebih dari itu, norma-norma dan kebiasaan yang dimiliki oleh masyarakat juga termasuk ke dalam lingkup budaya sehingga kebiasaan orang kampung ziarah kubur, selamatan, dan silaturrahmi seperti yang diceritakan dalam kutipan juga harus dijaga sebagai bentuk cerminan dari masyarakat tersebut, karena menunjukkan masyarakat yang lekat dengan sikap gotong royong dan tenggang rasa sehingga budaya dapat dijadikan sebagai salah satu haluan pembangunan nasional.

Maka berdasarkan beberapa kutipan mengenai permasalahan sosial delinkuensi dari kumpulan cerpen "Konvensi" tersebut, A. Mustofa Bisri ingin memberikan kritik beserta himbauan secara tidak langsung kepada masyarakat untuk tetap menjalankan norma-norma yang telah dijalankan oleh nenek moyang selama berabad-abad lamanya. Pada dasarnya, tidak ada satupun norma yang bersifat buruk atau menyesatkan. Semua norma bersifat mengatur kehidupan agar tetap terjalin dengan baik dan tidak terjadi perselisihan. Norma sendiri dapat dikatakan sebagai identitas dari lingkungan masyarakat dimana norma tersebut dijalankan.

\section{c. Alkoholisme}

Di negara Indonesia undang-undang mengenai minuman memabukkan (minuman keras), orang mabuk, penjual minuman yang memabukkan, membuat orang lain mabuk, bahkan sampai memaksa orang lain untuk minum segala minuman yang memabukkan telah diatur sedemikian rupa. Hal tersebut bertujuan untuk melindungi dan mengendalikan semua lapisan masyarakat dari bahaya minuman keras tersebut.

Alkohol dapat membuat seseorang merasa kecanduan dan biasanya dikonsumsi ketika orang tersebut mengalami stress atau depresi. Alkohol dinilai dapat menurunkan kadar depresi. Akibatnya ketika seseorang dilanda depresi pasti akan bergantung dengan alkohol. Tidak berhenti di situ, ketika orang tersebut telah mendapatkan ketenangan dengan alkohol maka ia akan mempengaruhi orang lain untuk melakukan hal serupa dengannya.

"Sebagai pemijat yang sudah lama bekerja sama dengn beberapa hotel, kadang-kadang saya diajak mengawani pelanggan saya untuk minum-minuman haram.” (Bisri, 2018: 114).

"Di kamar suamiku, aku menemukan lintingan rokok ganja." (Bisri, 2018: 103).

"Ini barang bahaya, Bu," sahutnya khawatir. "Ini ganja. Bisa gawat bila ketabuan!" (Bisri, 2018: 103).

Ganja merupakan barang-barang terlarang yang seharusnya tidak digunakan 
karena berbahaya. Efek negatif dari ganja adalah membuat orang semakin malas dan memperlambat kerja otak, meskipun masih banyak kontroversi dalam masalah tersebut. Namun tidak dapat dipungkiri bahwa ganja merupakan salah satu penyebab kematian yang ada di dunia akibat dari zat yang terkandung di dalamnya. Bahkan menurut Lickona (2015: 544), kegiatan mencampurkan alkohol dengan narkoba menjadikan meningkatnya angka kematian di Amerika Serikat menjadi 2.500 setiap tahunnya.

Kutipan yang menggambarkan kondisi masyarakat pecandu alkohol dan narkoba tersebut ditulis A. Mustofa Bisri pada rentan tahun 2005-2006. Memang fakta di lapangan selaras dengan hal yang diceritakan dalam cerpen. Seperti berita yang dilansir Detiknews bahwa Kepolisian Daerah Sulawesi Tengah merazia rumah tahanan yang diduga menjadi tempat peredaran minuman keras dan narkoba. Razia tersebut menemukan 10 bong (alat pengisap shabu-shabu), 56 botol minuman keras, dan 1 toples minuman dari campuran Cap Tikus dan Janin Rusa. Tambahan lagi, pada Jumat 29 Desember 2006 Detiknews juga memberitakan bahwa di Bali pada penghujung tahun melakukan pemusnahan terhadap barang bukti (barbuk) narkotika dan minuman keras. Di antaranya terdapat 2,156 kg heroin milik salah seorang anggota sindikat Bali Nine, Renae Lawrence (Asy: 2005).

\section{d. Homosesualitas}

Tidak ditemukan.

\subsection{Kemiskinan}

Konstruksi sosial sangat mempengaruhi adanya lapisan dalam masyarakat. Umumnya masyarakat berdasarkan strata ekonomi dibedakan menjadi dua, yaitu kaum proletar dan kaum borjuis. Adanya kultur yang dimiliki oleh kaum borjuis menjadikan ekonomi sebagai infrastruktur yang akhirya dapat memengaruhi superstruktur yang ditopang. Perhatikan kutipan berikut.

"Saya sedih melihat kawan-kawan di pedesaan, meski saya sudah berbuat banyak selama ini, masih banyak di antara mereka yang bidup di bawah garis kemiskinan. Perjuangan saya demi rakyat di daerah ini khususnya, belum selesai." (Bisri, 2018: 42).

"Saya sudah menyusun rencana secara bertahap yang saya perkirakan dalam masa lima tahun ke depan, akan paripurna pengentasan kemiskinan di daerah ini." (Bisri, 2018: 42).

Kenyataannya, antara konsep dan keadaan di lapangan sangatlah berbeda. Kutipan tersebut ternyata menggambarkan fakta di lapangan bahwa masalah kemiskinan sampai detik ini belum diselesaikan dengan maksimal. Masalah kemiskinan harus segera diatasi mulai dari peningkatan kemampuan kognitif penduduk yang masih rendah. Ketika seseorang memiliki kemampuan kognitif yang baik, maka secara otomatis ia dapat lebih handal untuk mengatur kehidupannya termasuk dalam segi ekonomis.

Kutipan-kutipan di atas ditulis oleh A. Mustofa Bisri dalam cerpen-cerpennya mulai tahun 2002-2018. Gambaran kondisi sosial masyarakat dari segi kemiskinan pada rentan tahun itu dapat dibuktikan melalui data presentase penduduk miskin, baik di desa maupun kota, yang dilakukan oleh BPS (Badan Pusat Statistik) Indonesia berikut ini. 
Tabel 1

Presentase Penduduk Miskin Indonesia Tahun 2002 - 2019

\begin{tabular}{|c|c|c|c|}
\hline NO & TAHUN & \multicolumn{2}{|c|}{ TAHUNAN } \\
\hline 1. & 2002 & \multicolumn{2}{|r|}{18.20} \\
\hline 2. & 2003 & \multicolumn{2}{|r|}{17.42} \\
\hline 3. & 2004 & \multicolumn{2}{|r|}{16.66} \\
\hline 4. & 2005 & \multicolumn{2}{|r|}{15.97} \\
\hline 5. & 2006 & \multicolumn{2}{|r|}{17.75} \\
\hline 6. & 2007 & \multicolumn{2}{|r|}{16.58} \\
\hline 7. & 2008 & \multicolumn{2}{|r|}{15.42} \\
\hline 8. & 2009 & \multicolumn{2}{|r|}{14.15} \\
\hline 9. & 2010 & \multicolumn{2}{|r|}{13.33} \\
\hline NO & TAHUN & I (Maret) & II (September) \\
\hline 10. & 2011 & 12.49 & 12.36 \\
\hline 11. & 2012 & 11.96 & 11.66 \\
\hline 12. & 2013 & 11.37 & 11.47 \\
\hline 13. & 2014 & 11.25 & 10.96 \\
\hline 14. & 2015 & 11.22 & 11.13 \\
\hline 15. & 2016 & 10.86 & 10.70 \\
\hline 16. & 2017 & 10.64 & 10.12 \\
\hline 17. & 2018 & 9.82 & 9.66 \\
\hline 18. & 2019 & 9.41 & 9.22 \\
\hline
\end{tabular}

Data presentase Badan Pusat Statistik Indonesia tersebut menunjukkan bahwa secara garis besar tingkat kemiskinan masyarakat Indonesia dari tahun ke tahun (2002 2019) mengalami penurunan kecuali pada tahun 2006, 2013, dan 2015 yakni mengalami kenaikan. Penurunan tingkat kemiskinan tersebut dirasa kurang maksimal karena tiap tahun tidak lebih dari 1,0\% kemiskinan dapat dituntaskan. Oleh karena itu pemerintah dan masyarakat harus bekerja sama dalam mengentas kemiskinan. Pemerintah hendaknya lebih dapat mengelola masyarakatnya dengan baik sementara masyarakat senantiasa mengembangkan kemampuan kognitifnya didukung dengan pendidikan yang disediakan oleh pemerintah agar dapat survive dalam hidupnya.

\subsection{Birokrasi}

Birokrasi merupakan bagian dari sebuah organisasi yang mana mempunyai rantai komando pembagian kerja dengan berbagai macam peraturan yang ketat. Birokrasi memiliki fungsi untuk melayani publik sejalan dengan peraturan yang ditetapkan oleh pemerintah. Selain itu, birokrasi juga mempunyai tujuan dan cita-cita sendiri. Birokrasi memiliki bentuk seperti piramida, artinya di bagian bawah memiliki lebih banyak anggota daripada di bagian atas. Orang-orang yang berada di bawah akan melakukan apa yang menjadi perintah atasannya. Perhatikan kutipan di bawah ini. 
"Karena keputusan sudah diambil, yaitu menghajar orang-orang yang mereka anggap telah merendabkan dan mengecewakan mereka, maka sepanjang malam, mereka tinggal membahas mengenai taktik dan strategi untuk melaksanakan keputusan itu." (Bisri, 2018: 12).

"Tidak," sergah Syabakhronni berang, "sekali lagi tidak!! Kita, paling tidak aku sendiri, tidak akan menghentikan permainan ini." (Bisri, 2018: 16).

"Saya akan memulai tradisi baru dalam pemerintahan daerah ini. Tradisi yang mengedepankan kejujuran dan tranparansi. Pemerintahan yang bersih. Kasiban rakyatyang sekian lamanya tidak mendapatkan haknya, karena kerakusan pemimpinnya." (Bisri, 2018: 46).

Kutipan mengenai pemimpin yang mempertahankan kekuasaan dan ingin memulai tradisi baru tersebut ditulis A. Mustofa Bisri pada tahun 2005 di era kepemimpinan Presiden Susilo Bambang Yudhoyono (SBY). Pada masa itu seperti yang diberitakan oleh Detiknews yakni pembangunan infrastruktur dengan tujuan pembentukan negara demokratis belum terbentuk. Hal tersebut mendapat penilaian dari pengamat politik LIPI, Bachtiar Effendy bahwa prediksi 10-15 tahun ke depan perdebatan mengenai Indonesia ke arah yang lebih baik masih berkutat pada masalah infrastruktur. Sementara pengamat politik internasional Zainuddin Jafar memberi nilai peran Indonesia di dunia internasional tidak akan berubah jika kepemimpinan di bawah SBY-JK tidak kembali bersatu dan kompak. Semua itu dikarenakan untuk ikut bermain di kancah politik internasional pemerintah harus kuat, terutama pemimpinnya (Umi, 2005).

Setiap pemimpin pasti seorang yang mengukir sejarah. Sejarah yang dibentuk tergantung pada kebijakan-kebijakan yang diambil. Marx (dalam Suseno, 2005: 141 142) berpendapat bahwa sejarah sama sekali tidak berhubungan dengan pikiran yang dimiliki oleh manusia, akan tetapi ditentukan oleh cara manusia menjalankan sistem produksinya. Oleh karenanya, untuk melakukan perubahan hidup manusia tidak bisa jika hanya mengandalkan perubahan cara berpikir tanpa dibarengi dengan perubahan sistem berproduksi.

Jadi, sejatinya birokasi merupakan sistem penggerak pemerintah dalam melakukan pelayanan dan pembangunan publik. Penyebab kendala dari pelaksanaan birokrasi yang kurang profesional adalah karena penurunan komitmen pemimpin. Penurunan komitmen pemimpin secara otomatis dibarengi dengan penurunan tanggung jawab sehingga perlu adanya transparansi kepada publik. Maka dari itu, dibutuhkan pemimpin yang kredibel, bersih, serta memiliki integritas tinggi sehingga dapat menjadi teladan bagi anggota-anggota di bawahnya.

\subsection{Kependudukan}

Semakin berkembang tingkat teknologi yang dikuasai oleh masyarakat berarti semakin kompleks pula pembagian lapisan masyarakat. Soekanto dan Sulistyowati (2015: 29) mengatakan bahwa masyarakat bukan semata-mata kumpulan dari orangorang yang tindakannya tidak berdasar. Kumpulan tersebut hidup dan berkembang sesuai dengan arahan dari organ-organ tertentu untuk melakukan fungsi-fungsinya.

"Diakuinya dirinya selama ini sibuk - kadang-kadang hingga berkelabi dengan kawan mengejar rezeki, sesuatu yang sebetulnya sudah dijamin Tuban untuknya. Sementara dia sambalewa dalam berusaba untuk berlaku lurus menjadi manusia yang baik, sesuatu yang dituntut Tuban." (Bisri, 2018: 28).

"Sementara banyak kawan-kawanku yang sudah lulus kuliah, masih lontang-lantung mencari pekerjaan." (Bisri, 2018: 97).

Banyaknya sarjana yang menganggur kebanyakan disebabkan oleh tujuan kuliah 
hanya untuk mendapatkan gelar. Selain itu, adanya pembagian kelas sosial dalam masyarakat turut memicu persaingan untuk memasuki kelas sosial atas. Sayangnya, persaingan itu tidak dilakukan dengan jalan yang baik dan benar sehingga menimbulkan keinginan untuk mendapatkan gelar dengan meghalalkan segala macam cara.

Kutipan di atas ditulis A. Mustofa Bisri pada tahun 2005. Fenomena yang terjadi pada masa itu memang seperti yang tergambar dalam cerpen berjudul "Sang Primadona" tersebut. Menurut Sanisah (2010: 147) pada tahun 2005 jumlah pengangguran lulusan sarjana lebih tinggi dari tahun 2006. Setelah itupun tingkat pengangguran lulusan sarjana juga semakin menghawatirkan setiap tahunnya. Perhatikan tabel berikut.

Tabel 2

Pengangguran Lulusan Sarjana

\begin{tabular}{|c|c|c|}
\hline NO & TAHUN & JUMLAH \\
\hline 1. & 2005 & $\begin{array}{c}385.538 \\
\text { orang }\end{array}$ \\
\hline 2. & 2006 & $\begin{array}{c}375.601 \\
\text { orang }\end{array}$ \\
\hline 3. & 2007 & $\begin{array}{c}409.890 \\
\text { orang }\end{array}$ \\
\hline
\end{tabular}

Perkembangan dewasa ini, seperti yang diberitakan kompas bahwa mahasiswa lulusan perguruan tinggi di Indonesia tengah mengalami dilema. Hal tersebut dikarenakan gelar ijazah yang diperoleh tidak menjamin untuk mendapatkan pekerjaan. Selain itu, mereka juga bersaing dengan tenaga kerja asing sebagai dampak dari MEA. Menurut data tahun 2014, pengangguran paling tinggi dialami oleh lulusan S1 dengan total 495.143 orang. Pengangguran yang banyak tersebut disebabkan kurangnya kesiapan mahasiswa untuk siap pakai dalam dunia kerja setelah lulus dari universitas (Gewati, 2016).

Dikuatkan oleh data Badan Pusat Statistik (BPS) per Februari 2019 memaparkan bahwa jumlah pengangguran di Indonesia memang semakin menurun. Namun, jumlah pengangguran mahasiswa lulusan diploma dan universitas semakin bertambah. Alasannya adalah instansi pendidikan hanya berfokus pada seberapa jauh siswa dapat menangkap kurikulum. Padahal ketika melamar pekerjaan juga dipertimbangkan mengenai karakter dan kecakapan seseorang. Oleh karena itu, Menteri Pendidikan dan Kebudayan, Nadiem Makarim mengatakan bahwa tidak semua sarjana mempunyai kompetensi baik. Namun, bukan berarti setiap orang tidak membutuhkan pendidikan (Hartanto, 2019).

\subsection{Kejahatan}

Kejahatan merupakan perbuatan tidak susila yang bersifat merugikan baik untuk pelaku maupun korban. Faktor-faktor penyebab kejahatan bermacam-macam, biasanya karena salah pergaulan atau kurangnya kontrol lingkungan. Biasanya kemiskinan juga dapat menjadi alasan untuk melakukan kejahatan.

'Njenengan tabu, orang-orang yang selama ini ada di sekeliling saya, yang resminya merupakan pembantu-pembantu saya, justru malab hanya mengganggu. Sering menjegal saya. Mereka sering mengambil kebijaksanaan sendiri dengan mengatasnamakan saya." (Bisri, 2018: 43).

"Sekarang ini beredar isu katanya bupati menyelewengkan dana ini-itu; bupati menyunati bantuan-batuan untuk masyarakat; bupati membangun rumah seharga sekian miliar di kampung asalnya; dan isu-isu negatif lain. Ini semua sumbernya ya mereka itu." (Bisri, 
2018: 43).

"Saya mohon restu dan dukungan Panjenengan. Saya berjanji dalam diri saya, kalau nanti saya terpilih lagi, akan saya sapu bersih sampab-sampah yang tak tabu diri itu dari lingkungan saya." (Bisri, 2018: 43).

Perkembangan ekonomi terjadi begitu cepat dan dapat memicu kejahatan. Berdasarkan konsep yang dipaparkan oleh Supriyadi (2003: 116) bahwa sosialisme secara konseptual dibedakan menjadi dua bentuk, yaitu sebagai sebuah ideologi yang secara resmi dapat mendukung kebijakan-kebijakan negara tentang reformasi ekonomi dan sosial serta sebagai bentuk pemikiran kritis yang memperoleh masukan dari protesprotes yang disampaikan oleh rakyat. Konsep tersebut secara tidak langsung berhubungan dengan apa yang digambarkan penulis A. Mustofa Bisri tentang keadaan masyarakat pada masa ia menulis cerpennya.

Sosialisme dijadikan sebagai ideologi digunakan sebagai alat untuk mengentas adanya ketimpangan ekonomi dan sebagai bukti pemikiran kritis atas ketidakadilan yang tengah terjadi di masyarakat. Sering kali ditemukan kasus-kasus penyelewengan yang dilakukan oleh aparat negara. Mulai dari tipe penyuapan sampai tipe penggelapan dana yang dapat merugikan berbagai pihak. Dibuktikan oleh data statistik Komisi Pemberantasan Korupsi (KPK) pada lamannya yang diperbarui tanggal 31 Desember 2019. Berdasarkan data yang ada di lapangan ketika A. Mustofa Bisri menuliskan cerpennya yaitu tahun 2005 adalah korupsi paling banyak dilakukan oleh sembilan komisi dengan sembilan eselon I/II/III yang melakukan korupsi dengan cara pengadaan barang/jasa serta penyuapan.

Penyebab dari tindakan korupsi tidak lain seperti yang tertulis oleh humas KPK dalam laman beritanya pada tanggal 3 Maret 2020, bahwa Firli Bahuri selaku Ketua Komisi Pemberantasan Korupsi (KPK) menjelaskan mengenai akar dari adanya tindakan korupsi tidak lain karena minimnya integritas. Hal tersebut dikarenakan rumus dari tindakan korupsi $=$ kekuasaan + kesempatan - integritas. Sebab lain adalah karena sistem birokrat itu sendiri yang memberikan celah untuk melakukan korupsi.

Meskipun kejahatan mempunyai bermacam-macam bentuk, tidak ada satupun tindakan yang dapat dibenarkan. Sudah pasti karena tidak ada tindakan kejahatan yang memiliki nilai positif. Meski berbagai macam cara telah digunakan untuk mengatur dan memberantas tindakan kejahatan, kenyataannya masih banyak masyarakat yang melakukan kejahatan terhadap sesamanya baik disengaja maupun tidak. Oleh karena itu, dasar-dasar moral yang kuat dapat menjadi solusi utama untuk memberantas kejahatan sehingga perlunya penanaman moral yang kuat mulai usia dini.

\subsection{Disorganisasi Keluarga}

Disorganisasi keluarga merupakan dampak dari kegagalan anggota keluarga dalam menjalankan peran dan tugasnya masing-masing. Kegagalan tersebut menumbuhkan hubungan yang tidak harmonis sehingga dapat berujung pada tindakan kekerasan fisik hingga perceraian. Disorganisasi keluarga pada umumnya terjadi karena sang suami sebagai kepala rumah tangga tidak dapat menjalankan perannya dengan baik. Perhatikan kutipan di bawah ini.

"Waktukupun tersita oleh kegiatan-kegiatan di luar rumah. Selain pekerjaanku sebagai artis, aku menikmati kegiatan-kegiatan pengajian." (Bisri, 2018: 101).

"Aku sudah semakin jarang di rumah. Kalaupun di rumah, perbatianku semakin minim terbadap anak-anak; apalagi terbadap suami yang semakin menyebalkan saja kelakuannya." (Bisri, 2018: 102-103).

"Yang lebih penting lagi adalah akibatnya pada masa depan anak-anakku. Aku sudah sering mendengar tentang nasib buruk yang menimpa anak-anak dari orang tua yang 
bercerai." (Bisri, 2018: 104).

Permasalahan sosial mengenai suami yang tidak dapat menjalankan perannya dengan baik akhirnya menimbulkan kepincangan peran istrinya sehingga menimbulkan keinginan untuk bercerai. Kutipan-kutipan tersebut ditulis oleh A. Mustofa Bisri dalam cerpennya pada tahun 2005. Menurut data di lapangan yang diberitakan Detiknews adalah Dirjen Bimas Islam Depag Nazaruddin Umar memaparkan data pengadilan agama yakni angka perceraian sebab poligami pada tahun 2004 sebanyak 813 kasus, tahun 2005 naik menjadi 879 kasus, dan tahun 2006 naik lagi menjadi 983 kasus. Artinya, setiap tahun angka perceraian semakin naik sehingga menimbulkan A. Mustofa Bisri mengangkat kasus disorganisasi keluarga ke dalam cerpennya pada masa itu (Umi, 2007).

Menyikapi kasus tersebut, dibutuhkan pendidikan moral efektif yang dapat membuahkan sikap hormat dari orang tua kepada anak-anaknya sejak usia dini. Sikap hormat tersebut dapat digunakan sebagai pondasi dalam menyikapi segala hal. Menurut Lickona (2015: 49-50) dikuatkan oleh penelitian sederhana pada ribun anak SMP dan SMA yang menyatakan bahwa semakin baik pengontrolan seorang ibu terhadap anakanaknya maka semakin baik pula komunikasi yang terjalin antara anak dengan ayahnya. Akhirnya, semakin baik hubungan antara anak dan orang tuanya maka semakin baik pula moral anak sehingga kecil kemungkinan terlibat masalah hukum.

Maka dari itu, untuk melahirkan anak-anak bangsa yang berkompeten dan bermoral bagus harus dimulai dari keluarga yang harmonis. Suasana keluarga yang positif dapat memicu rasa nyaman, aman, dan damai untuk anak apabila berada di tengah keluaganya. Suasana keluarga yang harmonis melahirkan sikap saling pengertian serta peduli akan hidup bersama-sama sebelum terjun ke dalam hidup bermasyarakat dan bernegara. Sikap-sikap positif tersebut akhirnya melekat pada karakter anak sehinga tercipta budaya yang berkualitas.

\subsection{Lingkungan Hidup}

Lingkungan hidup membentuk kesatuan ruang semua benda guna menciptakan dan mempengaruhi antara satu dengan yang lainnya. Lingkungan hidup juga termasuk di dalamnya adalah ekosistem, budaya, dan perilaku-perilaku sosial. Oleh karena itu, manusia beserta perilakunya dapat memengaruhi kesejahteraan hidup dirinya dan juga makhluk-makhluk di sekelilingnya. Kutipan berikut menunjukkan salah satu perilaku manusia yang dapat mempengaruhi lingkungan sekitarnya.

"Tapi ada juga timbal-baliknya. Saat pulang, mereka tidak lupa meninggalkan amplop yang isinya lumayan." (Bisri, 2018: 41).

Kutipan tersebut ditulis A. Mustofa Bisri pada tahun 2005 dengan fenomena politik yang kurang bersih. Dibuktikan oleh data statistik Tindak Pidana Korupsi (TPK) berdasarkan jenis perkara oleh Komisi Pemberantasan Korupsi (KPK) pada lamannya yang diperbarui tanggal 31 Desember 2019. Data tersebut memaparkan bahwa pada tahun 2005 terjadi sebanyak 19 perkara korupsi dengan rincian 7 kasus penyuapan dan 12 kasus pengadaan barang atau jasa. Kutipan berikut menggambarkan kondisi lingkungan kooperasi.

Oleh karena itu, sebagai bangsa yang beradab dan berbudaya kita harus senantiasa menjaga dan melindungi lingkungan sekitar dengan baik. Hal itu dikarenakan dalam menjalani kehidupan kita tidakk dapat lepas dengan lingkungan. Jika kita hidup dalam lingkungan yang baik maka kita akan memiliki kehidupan yang baik pula, begitupun sebaliknya.

\subsection{Generasi Muda dalam Masyarakat Moderen}

Permasalahan yang dimiliki oleh kaum muda biasanya ditandai oleh dua hal, 
yaitu sikap apatis atau melawan. Soekanto dan Sulistyowati (2015: 325-326) menjelaskan bahwa generasi muda pada umumnya juga mengalami permasalahan terkait biologis dan sosial. Masyarakat tidak hanya menuntut adanya kedewasaan secara fisik bagi generasi muda. Akan tetapi juga kedewasaan sosial. Adanya perbedaan pola pikir antara generasi muda dan generasi tua pada masyarakat yang sedang mengalami transisi, menyebabkan terjepitnya generasi muda terhadap norma-norma lama yang sudah mendarah daging. Berikut contoh generasi muda yang mencerminkan sikap melawan.

"Anak sulungnya itu tak mau bersalaman dengan kedua orang tuanya. Bersentubanpun katanya haram. Tono menganggap kedua orang tuanya kafir dan najis, sebelum ikut baiat jamaabnya." (Bisri, 2018: 92).

"Anak, perempuannya itu, kata kawan-kawannya sudah dikawin oleh imam jamaahnya; tapi tak ada seorangpun yang tahu di mana mereka tinggal." (Bisri, 2018: 92).

Maka dari itu, Syari'ati berpendapat bahwa wajib hukumnya bagi bangsa-bangsa Muslim untuk menengok kembali akar-akar tradisi yang mana dapat dijadikan sebagai sikap untuk melawan budaya para penjajah. Syari'ati meyakini bahwa setiap masyarakat mempunyai ekspresi budaya yang baik (Supriyadi, 2003: 160). Oleh karenanya, kita harus senantiasa memilah dan memilih apa saja sebelum menerapkan dalam kehidupan sehari-hari. Tujuannya adalah untuk kebaikan bersama dalam masyarakat yang homogen.

Kutipan tersebut ditulis oleh A. Mustofa Bisri pada tahun 2018. Pada tahun itu isu tentang Hizbut Tahrir Indonesia (HTI) sedang mengalami masa panas-panasnya. Dibuktikan dari berita dalam Republika bahwa Majelis Hakim menuturkan jika HTI terbukti menyebarkan dan memperjuangkan paham khilafah, sesuai dengan video Muktamar HTI tahun 2013 silam. Majelis mengatakan pemikiran khilafah sepanjang masih dalam sebatas konsep dipersilakan. Namun bila sudah diwujudkan dalam aksi yang berupaya mengganti Pancasila, maka dapat berpotensi perpecahan (Nugroho dan Purwadi, 2018).

Dikuatkan Puspita (2018) dalam berita Republika bahwa Tjahjo Kumolo, selaku Menteri Dalam Negeri juga menjelaskan adanya organisasi kemasyarakatan (ormas) Hizbut Tahrir Indonesia (HTI) yang hendak mengubah ideologi Pancasila dan dasar negara. Hal tersebut yang akhirnya menjadikan pemerintah membubarkan ormas tersebut. Berdasarkan kasus-kasus yang tengah merambak dalam kehidupan masyarakat tersebut mengharuskan kita lebih peduli terhadap keselamatan hidup berbangsa. Memperkenalkan sekaligus menanamkan budaya lokal dan moral kepada anak sejak usia dini sangat dianjurkan agar kepribadian baik semakin tertanam. Kepribadian masyarakat Indonesia yang selalu berpegang teguh pada pancasila, menghormati jasajasa pahlawan, menghargai perbedaan, tenggang rasa, serta toleransi pada umat yang berbeda agama.

\subsection{Peperangan}

Peperangan tidak melulu berhubungan dengan senjata-senjata tajam. Di era globalisasi ini, peperangan dapat menimbulkan lebih banyak kerusakan daripada masa lampau karena didukung adanya perkembangan industri dan teknologi. Semakin maju peradaban manusia berarti semakin banyak penderitaan yang akan dialami. Penderitaan dapat muncul dari berbagai macam sektor seperti politik, hukum, militer, sosial, ekonomi, bahkan agama. Penyebab dari peperangan sangat berbeda-beda karena adanya perbedaan kepentingan.

"Kiai Sabil adalah seorang tokoh sangat berpengaruh di daerah kami. Partai terbesar di sini tak bakalan mengambil keputusan apapun tanpa restu dan persetujuan kiai yang satu 
ini." (Bisri, 2018: 44).

"Meski balai desa boleh dikata sudah tidak memiliki apa-apa, anehnya mereka yang merasa pantas memimpin masih saja berebut berusaha menduduki kelurahan dengan mengerahkan para pendukungnya. Setiap haripun tawuran massal tak terelakkan." (Bisri, 2018: 66).

"Setiap hari mayat berjatuban. Korban-korban yang terluka terus bertambah dan bertambah. Tapi tak seorangpun yang peduli. Perebutan terus berlangsung.” (Bisri, 2018: 66).

Bagi Karl Marx, manusia pada dasarnya harus menjadi makhluk sosial. Artinya, manusia mampu menemukan sebuah kepuasan dari dalam dirinya terhadap segala hal terutama tentang sistem yang mengatur hidupnya. Kenyataannya di lapangan, manusia malah saling menjatuhkan dan beradu sehingga yang seharusnya menjadi makhluk sosial malah merasa terasing terhadap dirinya sendiri (Anam, 2008: 190). Risikonya, semakin banyak pertikaian yang ditemukan di mana-mana.

Kutipan di atas ditulis A. Mustofa Bisri pada rentan tahun 2005-2006. Begitulah pola politik yang seperti diturunkan dari tahun ke tahun hingga saat ini. Sejalan dengan opini yang ditulis Sobari (2020) dalam Jawa Pos mengenai ironi politik sering terjadi dalam hubungan antara partai politik (parpol) dan pemilihan kepala daerah (pilkada) langsung. Semangat dan prakarsa organ parpol di daerah harus tunduk pada keputusan pimpinan pusat soal pasangan bakal calon kepala daerah yang diusung. Kondisi tersebut dapat merugikan perkembangan parpol dan kaderisasi politik di daerah. Imbasnya adalah beberapa calon yang ditetapkan kuasa pimpinan pusat berakhir gagal karena capaian kinerjanya yang tidak konsisten. Gagasan dan figur kader daerah justru tertekan oleh kuatnya keputusan pembesar parpol di Jakarta.

\section{PENUTUP}

Berdasarkan hasil penelitian yang telah dilakukan terhadap kumpulan cerpen "Konvensi" karya A. Mustofa Bisri, maka dapat diambil kesimpulan bahwa penelitian terhadap kritik sosial dalam kumpulan cerpen "Konvensi" karya A. Mustofa Bisri adalah mengenai permasalahan-permasalahan sosial yang dialami oleh masyarakat. Berdasarkan jenisnya, permasalahan sosial dibedakan mejadi sembilan macam, yaitu pelanggaran terhadap norma masyarakat, kemiskinan, birokrasi, kependudukan, kejahatan, disorganisasi keluarga, lingkungan hidup, generasi muda dalam masyarakat moderen, dan peperangan.

Memang bermacam-macam masalah tengah dijalani masyarakat. Akan tetapi, pada dasarnya akar permasalahannya adalah satu, yaitu akibat dari adanya degradasi moral. Kritik sosial dapat digunakan sebagai salah satu alat untuk mengontrol kondisi sosial masyarakat. Oleh karena itu, dengan adanya kritik sosial yang tepat maka dapat membenahi sistem atau perilaku menyimpang masyarakat yang dilakukan baik sadar maupun tidak.

\section{DAFTAR PUSTAKA}

Abidin, Muhammad Zainal. 2016. Kritik Sosial dalam Kumpulan Cerpen Lukisan Kaligrafi Karya A. Mustofa Bisri dan Implikasinya Terbadap Pembelajaran Bahasa dan Sastra Indonesia di SMA. Jakarta: Universitas Islam Negeri Syarif Hidayatullah Jakarta.

Anam, Munir Che. 2008. Mubammad SAW dan Karl Marx Tentang Masyarakat Tanpa Kelas. Yogyakarta: Pustaka Pelajar.

Asy. 2005. Berantas Narkoba, Polisi Razia Rutan Palu. bttps://news.detik.com/berita/d408643/berantas narkoba-polisi-raziarutan-palu (diunduh 12 Juni 2020). 
Badan Pusat Statistik. Presentase Penduduk Miskin Menurut Provinsi 2007-2019. https:// www.bps.go.id/dynamictable/2016/08/18/1219/persentase-pendudu k-miskin-menurutprovinsi-2007---2019.html (diunduh 28 Mei 2020). - Jumlah Penduduk Miskin, Presentase Penduduk Miskin dan Garis Kemiskinan,1970-2017. bttps:// wnw.bps.go.id/statictable/2014/01/30/1494/jumlabpendudukmiski n-persentase-penduduk-miskin-dan-garis-kemiskinan-1970-2017.btml (diunduh 12 Juni 2020).

Bisri, A. Mustofa. 2018. Kumpulan Cerpen Konvensi. Yogyakarta: DIVA Press.

Endaswara, Suwardi. 2013. Sosiologi Sastra Studi, Teori, dan Intepretasi. Yogyakarta: Penerbit Ombak.

Escarpit, Robert. 2008. Sosiologi Sastra. Jakarta: Yayasan Obor Indonesia.

Gewati, Mikhael. 2016. Kenapa Lulusan Perguruan Tinggi Makin Susah Mendapat Pekerjaan. bttps:/ / edukasi.kompas.com/read/2016/04/23/17424071/

Kenapa.Lulusan.Perguruan.Tinggi.Makin.Susah.Mendapat.Pekerjaan.?page=all (diunduh 3 Juni 2020).

Hartanto, Agas Putra. 2019. Praktisi Pendidikan Ungkap Penyebab Banyak Sarjana Menganggur. https://www.jawapos.com/nasional/15/12/2019/praktisi-pendidikanungkap-penye bab-banyak-sarjana-menganggur/ (diunduh 3 Juni 2020).

KPK. Statistik TPK Berdasarkan Instansi. https:// wmw.kpk.go.id/id/statistik/penindakan/tpk. -berdasarkan-instansi (diunduh 9 Juni 2020).

- Statistik TPK Berdasarkan Profesi atau Jabatan. https:// www.kpk.go.id/id/statistik/penindakan/tpk-berdasarkan-profesi-jabatan (diunduh 9 Juni 2020). 